\title{
The evaluation of analgesic effects of milnacipran and sertraline in tail-flick test
}

\author{
Kesim M, Yanik MN, Kadioglu M, Pepeoglu D, Erkoseoglu I, Kalyoncu NI, Yaris E \\ Karadeniz Technical University, Faculty of Medicine, Department of Pharmacology Trabzon, Turkey. \\ muratkesim@gmail.com
}

\begin{abstract}
Introduction: Antidepressant drugs are used in the treatment of pain as an adjuvant or alone. It has been shown that antidepressant drugs have analgesic effects in various diseases (diabetic neuropathy, low back pain, cancer pain etc.) Sertraline is a potent serotonin re-uptake inhibitor. Some antidepressant drugs inhibited both of the reuptake of serotonin and of noradrenaline. These drugs are called serotonin-noradrenaline re-uptake inhibitors (SNRIs). Milnacipran is a serotonin-noradrenaline re-uptake inhibitor. We have studied the analgesic effects of sertraline and milnacipran after acute and chronic application in tail-flick test in mice.

Methods: The analgesic effects of milnacipran $(10,30,50 \mathrm{mg} / \mathrm{kg})$ and sertraline $(10,20,50 \mathrm{mg} / \mathrm{kg})$ were measured after acute and chronic application in tail flick test. The analgesic effects of milnacipran $(30 \mathrm{mg} / \mathrm{kg})$ or sertraline $(50 \mathrm{mg} / \mathrm{kg})$ were evaluated after the application of L-NAME $(10 \mathrm{mg} / \mathrm{kg})$, naloxone $(5 \mathrm{mg} / \mathrm{kg})$, prazosin $(1 \mathrm{mg} / \mathrm{kg})$, ondansetron $(0.1 \mathrm{mg} / \mathrm{kg})$ in tail flick test.

Results: Milnacipran $(30 \mathrm{mg} / \mathrm{kg})$ and sertraline $(50 \mathrm{mg} / \mathrm{kg})$ produced statistically significant analgesic effect compared to their control values after acute and chronic application in tail-flick test. The analgesic effects of both milnacipran $(30 \mathrm{mg} / \mathrm{kg})$ and sertraline $(50 \mathrm{mg} / \mathrm{kg})$ in the presence of L-NAME $(10 \mathrm{mg} / \mathrm{kg})$, naloxone $(5 \mathrm{mg} / \mathrm{kg})$, ondansetron $(0.1 \mathrm{mg} / \mathrm{kg})$ and prazosin $(1 \mathrm{mg} / \mathrm{kg})$ were inhibited in tail-flick test.

Conclusion: These results indicate that the analgesic effects of milnacipran and sertraline are related to nitrergic, opioidergic, serotonergic and adrenergic system (Fig. 8, Ref. 23). Text in PDF www.elis.sk.

Key words: Milnacipran, Sertraline, Analgesia, Tail-flick test, mice.
\end{abstract}

Pain is the result of noxious thermal, mechanical, or chemical stimuli at the peripheral terminals of specialized primary afferent neurons ( $\mathrm{C}$ and $\mathrm{A} \delta$ fibers) called nociceptor. Several cytokines (interferon- $\gamma$, tumor necrosis factor- $\alpha$, interleukins) are released from damaged tissue. These cytokines cause release of hyperalgesic neuromediators (such as prostaglandins, serotonin), nitric oxide and opioid peptides and they contribute to anti-inflammatory and analgesic processes (1-6).

The dorsal horn of the spinal cord is an important site in the modulation of synaptic transmission of nociception from the periphery to the central nervous system. Also, serotonin and noradrenaline contribute to transmission of nociception in modulating descending inhibitor pain pathways at spinal and supraspinal levels $(7,8)$.

Selective serotonin re-uptake inhibitors (SSRIs) are antidepressant drugs. SSRIs are often used in treatment of psychiatric disorders. Also, antidepressant drugs are used in the treatment of pain as an adjuvant or alone. It has been shown that antidepressant drugs have analgesic effect in various diseases (diabetic neuropa-

Karadeniz Technical University, Faculty of Medicine, Department of Pharmacology, Trabzon, Turkey

Address for correspondence: M. Kesim, MD, Karadeniz Technical University, Faculty of Medicine, Department of Pharmacology, TR-61080 Trabzon, Turkey.

Phone: +90.462.3777841, Fax: +90.462-3777841

Acknowledgements: This study was supported by Karadeniz Technical University Research Fund (Grant No: 2009.114.001.6). thy, low back pain, cancer pain etc.) (9-13). Sertraline is a potent serotonin re-uptake inhibitors. Some antidepressant drugs inhibit both, the reuptake of serotonin and of noradrenaline. These drugs are called serotonin-noradrenaline re-uptake inhibitors (SNRIs). It has been shown that SNRIs attenuated pain inhibition via both serotonin and noradrenaline pathways in rat (14). Milnacipran is a serotonin-noradrenaline re-uptake inhibitor.

There are many studies showing the analgesic effect of antidepressant drugs in the literature. But their mechanism of antinociceptive action is not clear. Their mechanisms of antinociceptive action may be related to serotonergic and/or noradrenergic pathways, opioidergic and nitrergic system. We have studied the analgesic effect of sertraline and milnacipran after acute and chronic application in tail-flick test in mice.

\section{Methods}

The study was performed at the Karadeniz Technical University, Faculty of Medicine, Behavioral Pharmacology Laboratory of Department of Pharmacology. Balb/c mice of either sex weighting 20-40 g were randomly used in experiments. All of the animals were housed in cages with free access to food and water. The cages were placed in a quiet and temperature-humidity controlled room $\left(22 \pm 2{ }^{\circ} \mathrm{C}\right.$ and $60+5 \%$, respectively) in which a $12.12 \mathrm{~h}$ light-dark cycle was maintained. Experiments were conducted between 9.00 and $17.00 \mathrm{~h}$ to minimize the diurnal variation. The experimental 
protocol was approved by the Local Ethics Committee of Faculty of Medicine, Karadeniz Technical University (approval number: 2010/14). Tail-flick test was used to evaluate the analgesic effect.

\section{Tail-flick test}

The tail flick latency of each animal was obtained before drug administration (pretreatment value). The tail flick latencies (post treatment value) were measured at $2 \mathrm{nd} \mathrm{hr}$ after the administration of drugs. A cut off time of 30 second was selected in order to avoid any tissue damage in the animal. Results of tail flick latencies were expressed in terms of reaction time in seconds.

\section{Statistical analyses}

The data were expressed as the mean + SE. Statistical analyses were performed using SPSS software version 17. Statistical analyses for the comparison of the changes in measured data by time were carried out using Freidman test-due to violations of parametric test assumptions (non-normal distribution)- followed by Wilcoxon Signed Ranks test to show the significance of pairwise differences. The level of significance was set at $\mathrm{p}<0.05$.

\section{Drugs}

Milnacipran (Pierre Fabre-Biofarma, Turkey), sertraline (Sanovel, Turkey), prazosin HCl (Sigma.,USA), L-NAME (Lnitro arginine methyl ester hydrochlor; nitric oxide syntheses inhibitor) (Sigma, USA), naloxone $\mathrm{HCl}$ (opioidergic receptor antagonist) (Sigma, USA), ondansetron HCI (Sigma, USA) were dissolved in distilled water. Milnacipran and sertraline were administrated via oral gavage. Prazosin $\mathrm{HCl}$, L-NAME, naloxone $\mathrm{HCl}$ and ondansetron $\mathrm{HCl}$ were administrated intraperitoneally in a dose volume of no more than $10 \mathrm{ml} / \mathrm{kg}$ of mouse.

\section{Experimental protocols}

Mice were divided into the following experimental groups:

Group 1 (acute application groups)

- Milnacipran $(10 \mathrm{mg} / \mathrm{kg})$ group $(\mathrm{n}=6)$

- Milnacipran $(30 \mathrm{mg} / \mathrm{kg})$ group $(\mathrm{n}=6)$

- Milnacipran $(50 \mathrm{mg} / \mathrm{kg})$ group $(\mathrm{n}=6)$

- Sertraline $(10 \mathrm{mg} / \mathrm{kg})$ group $(\mathrm{n}=6)$

- Sertraline $(20 \mathrm{mg} / \mathrm{kg})$ group $(\mathrm{n}=6)$

- Sertraline $(50 \mathrm{mg} / \mathrm{kg})$ group $(\mathrm{n}=6)$

Group 2 (chronic application groups)

- Milnacipran $(30 \mathrm{mg} / \mathrm{kg})$ group $(\mathrm{n}=6)$

- Sertraline $(50 \mathrm{mg} / \mathrm{kg})$ group $(\mathrm{n}=6)$

Group 3 (Investigation of mechanism groups)

- Milnacipran $(30 \mathrm{mg} / \mathrm{kg})+$ Naloxone $(5 \mathrm{mg} / \mathrm{kg})$ group $(\mathrm{n}=6)$

- Milnacipran $(30 \mathrm{mg} / \mathrm{kg})+$ Ondansetron $(0.1 \mathrm{mg} / \mathrm{kg})$ group $(\mathrm{n}=6)$

- Sertralin $(50 \mathrm{mg} / \mathrm{kg})+$ Naloxone $(5 \mathrm{mg} / \mathrm{kg})$ group $(\mathrm{n}=6)$

- Sertralin $(50 \mathrm{mg} / \mathrm{kg})+$ Ondansetron $(0,1 \mathrm{mg} / \mathrm{kg})$ group $(\mathrm{n}=6)$

- Milnacipran $(30 \mathrm{mg} / \mathrm{kg})+$ L-NAME $(10 \mathrm{mg} / \mathrm{kg})$ group $(\mathrm{n}=6)$

- Sertraline $(30 \mathrm{mg} / \mathrm{kg})+$ L-NAME $(10 \mathrm{mg} / \mathrm{kg})$ group $(\mathrm{n}=6)$

- Milnacipran $(30 \mathrm{mg} / \mathrm{kg})+\operatorname{prazosin}(1 \mathrm{mg} / \mathrm{kg})$ group $(\mathrm{n}=6)$

- Sertraline $(50 \mathrm{mg} / \mathrm{kg})++\operatorname{prazosin}(1 \mathrm{mg} / \mathrm{kg})$ group $(\mathrm{n}=6)$

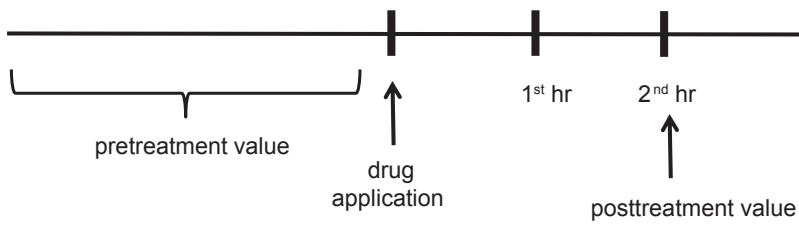

Fig. 1. Protocol of drug application in tail-flick test.

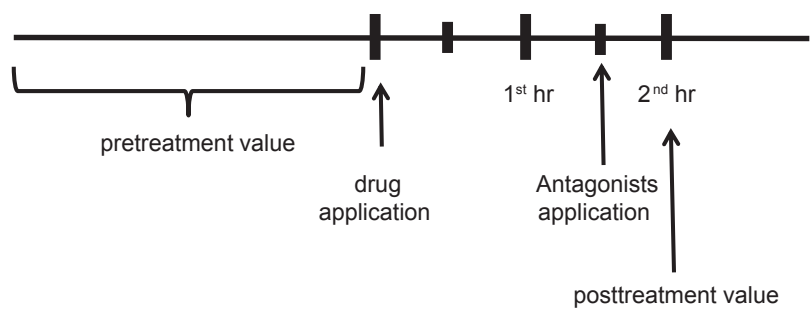

Fig. 2. Protocol of investigation of analgesic mechanisms in tail flick test.

Group 1 (acute application groups): Milnacipran (10, 30, 50 $\mathrm{mg} / \mathrm{kg})$ and sertraline $(10,20,50 \mathrm{mg} / \mathrm{kg})$ were administered via oral gavage. Control (pretreatment value) and post treatment (after drugs application) values in 2nd hr were measured by tail-flick test (Fig. 1).

Group 2 (Chronic application groups): Milnacipran (30 mg/kg) and sertraline $(50 \mathrm{mg} / \mathrm{kg})$ were administered via oral gavage once daily for 14 days in mice. At the end of 14 days, control (pretreatment value) and post treatment (after drugs application) values in 2nd hr were measured in tail-flick test.

Group 3 (Investigation of the mechanism groups):

Control values (pretreatment value) were measured in tail-flick test. Antagonists were administered intraperitoneally after 90 minute of treatment with milnacipran $(30 \mathrm{mg} / \mathrm{kg})$ or sertraline $(50 \mathrm{mg} / \mathrm{kg})$ via oral gavage. Post treatment values in $2 \mathrm{nd} \mathrm{hr}$ after milnacipran $(30 \mathrm{mg}$ / $\mathrm{kg}$ ) or sertraline $(50 \mathrm{mg} / \mathrm{kg}$ ) were measured by tail flick test (Fig. 2).

\section{Results}

Milnacipran $(30,50 \mathrm{mg} / \mathrm{kg})$ and sertraline $(50 \mathrm{mg} / \mathrm{kg})$ produced statistically significant analgesic effects compared to their control values after 2 hours in tail-flick test in group 1 (Figs 3 and 4) $(\mathrm{p}<0.05)$. However milnacipran $(10 \mathrm{mg} / \mathrm{kg})$ and sertraline (10, $20 \mathrm{mg} / \mathrm{kg}$ ) did not produce statistically significant analgesic effects compared to their control after 2 hours in tail-flick test (Figs 3 and 4).

Milnacipran $(30 \mathrm{mg} / \mathrm{kg})$ and sertraline $(50 \mathrm{mg} / \mathrm{kg})$ produced statistically significant analgesic effects compared to their control values after 2 hours in tail flick test in group 2 (Figs 5 and 6$)(\mathrm{p}<0.05)$.

The analgesic effects of both milnacipran $(30 \mathrm{mg} / \mathrm{kg})$ and sertraline $(50 \mathrm{mg} / \mathrm{kg})$ in the presence of L-NAME $(10 \mathrm{mg} / \mathrm{kg})$, naloxone $(5$ $\mathrm{mg} / \mathrm{kg})$, ondansetron $(0.1 \mathrm{mg} / \mathrm{kg})$ and prazosin $(1 \mathrm{mg} / \mathrm{kg})$ were inhibited after 2 hours in tail-flick test in group 3 (Figs 7 and 8$)(\mathrm{p}<0.05)$.

\section{Discussion}

Selective serotonin reuptake inhibitors (SSRI) that are mainly used in the treatment of psychiatric disorder are also preferred in the treatment of some pain syndromes as adjuvant or alone. 


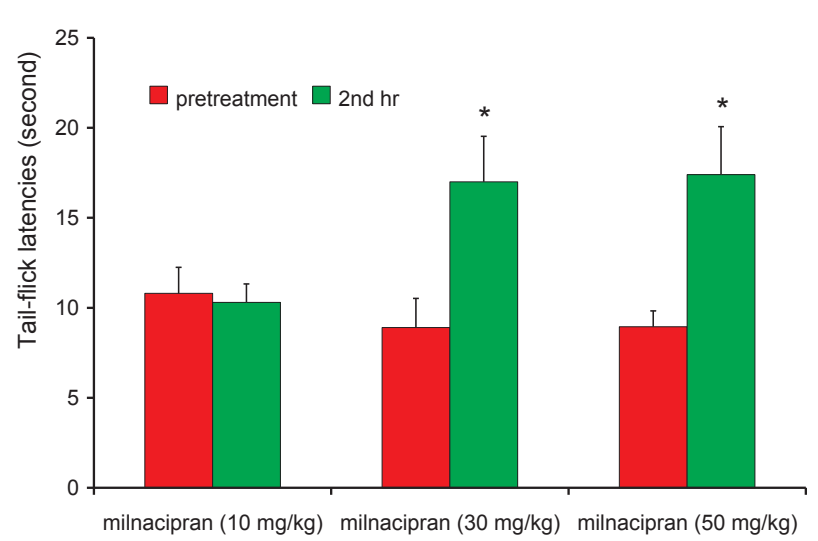

Fig. 3. Analgesic effect of milnacipran $(10,30,50 \mathrm{mg} / \mathrm{kg})$ in tail flick test. *: compared to own control $(p<0.05)$.

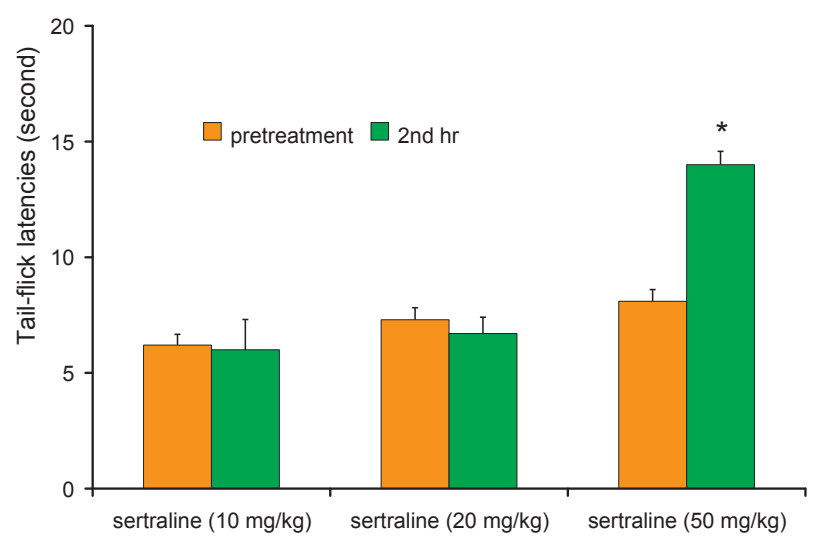

Fig. 4. Analgesic effect of sertraline $(10,20,50 \mathrm{mg} / \mathrm{kg})$ in tail flick test. *: compared to own control $(\mathbf{p}<0.05)$.

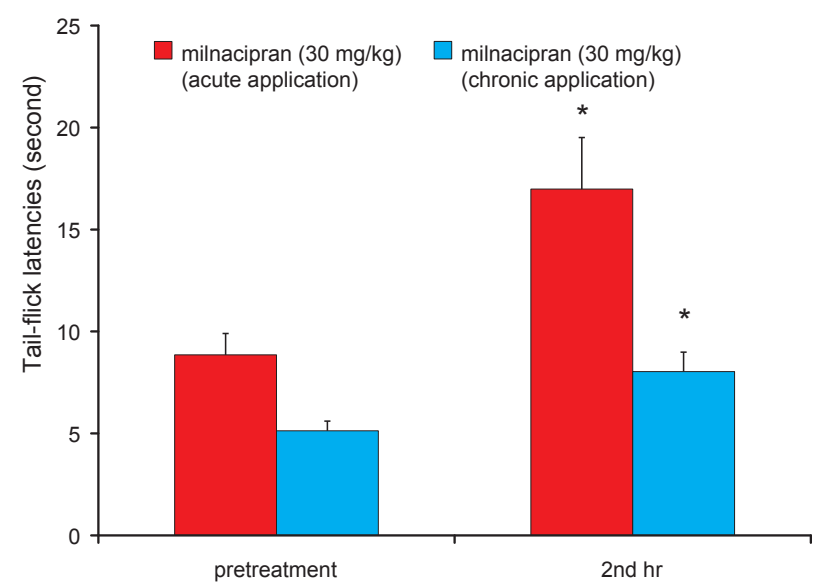

Fig. 5. Analgesic effect of milnacipran $(30 \mathrm{mg} / \mathrm{kg})$ after chronic application in tail flick test. *: compared to own control $(p<0.05)$.

Sertraline and milnacipran are in the class of SSRIs. These drugs inhibit serotonin reuptake in synaptic junction. Milnacipran also inhibits noradrenaline with serotonin. We have studied the analgesic effects of milnacipran and sertraline after acute and chronic application in tail flick test.

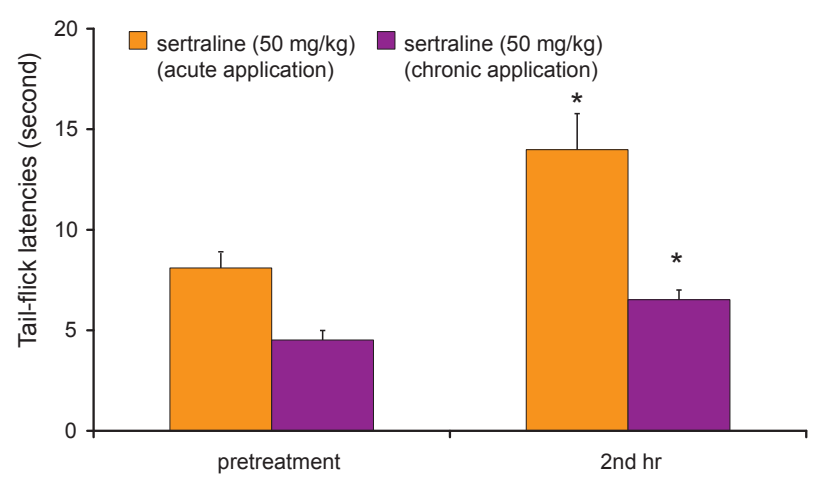

Fig. 6. Analgesic effect of sertraline $(50 \mathrm{mg} / \mathrm{kg})$ after chronic application in tail flick test. *: compared to own control $(p<0.05)$.

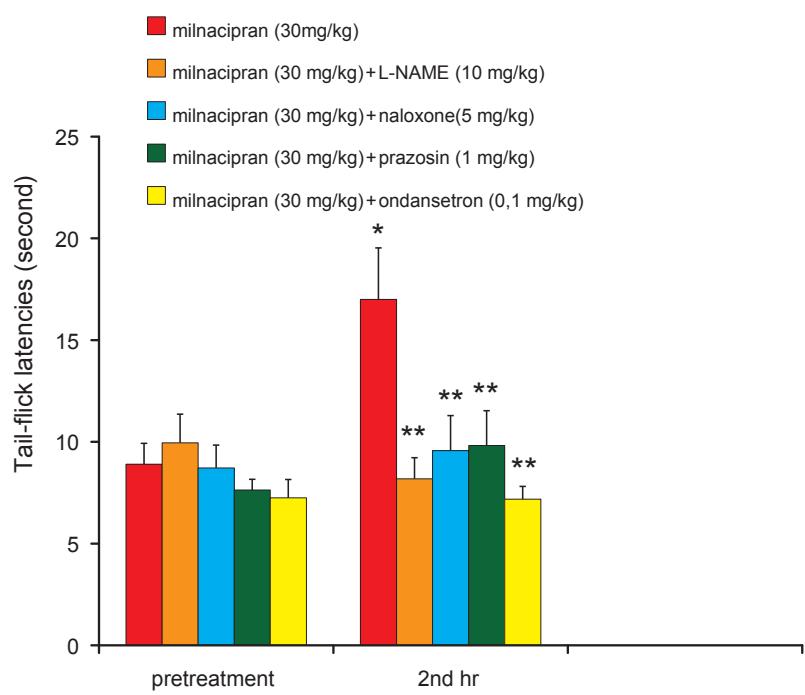

Fig. 7. Investigation of analgesic mechanism of milnacipran $(30 \mathrm{mg} / \mathrm{kg})$ in tail flick test. *: compared to own control $(p<0.05) . * *$ : compared to analgesic effect of milnacipran $(30 \mathrm{mg} / \mathrm{kg})(\mathbf{p}<0.05)$.

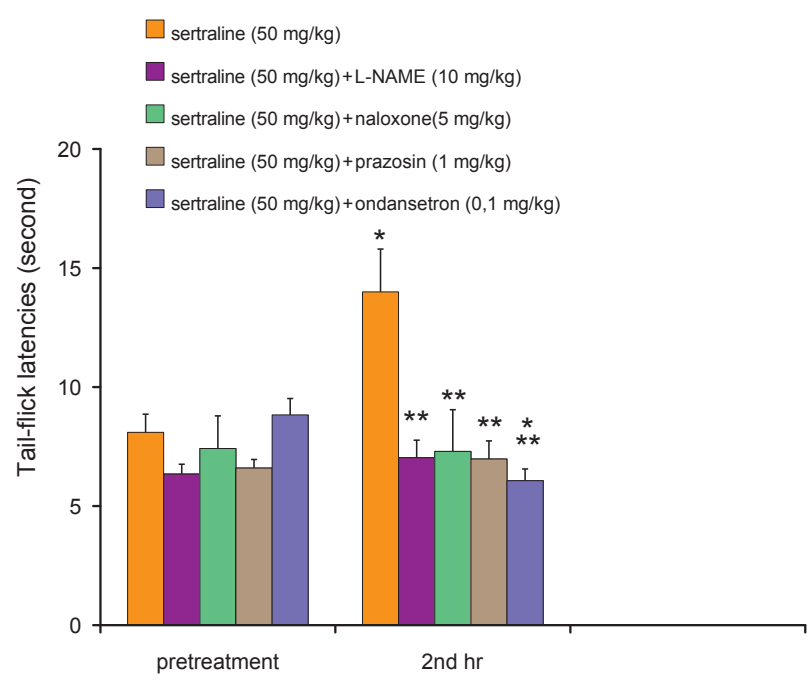

Fig. 8. Investigation of analgesic mechanism of sertraline $(50 \mathrm{mg} / \mathrm{kg})$ in tail flick test. *: compared to own control $(p<0.05)$, **: compared to analgesic effect of sertraline $(50 \mathrm{mg} / \mathrm{kg})(\mathrm{p}<0.05)$. 
Milnacipran $(30,50 \mathrm{mg} / \mathrm{kg})$ and sertraline $(50 \mathrm{mg} / \mathrm{kg})$ produced statistically significant analgesic effects compared to their control values after 2 hours in tail-flick test. The analgesic effects of both milnacipran $(30 \mathrm{mg} / \mathrm{kg})$ and sertraline $(50 \mathrm{mg} / \mathrm{kg})$ in the presence of L-NAME, naloxone, ondansetron and prazosin were inhibited after 2 hours in tail-flick test.

Onal et al (15) showed that antihyperalgesic effect of milnacipran is prevented by $\alpha$-methyl-p-tyrosine (inhibitor of noradrenaline synthesis), parachlorophenylalanine (inhibitor of serotonin synthesis) and naloxone (antagonist of opioidergic receptors) in neuropathic pain in rat. Yokogawa et al (16) have reported that norepinephrine reuptake inhibitor (nisoxetine, nortriptyline, maprotiline) and norepinephrine-serotonin reuptake inhibitor (imipramine, milnacipran) drugs induced dose-dependent antinociception in rat in formalin test. The analgesic effects of these antidepressants are antagonized by prazosin ( $\alpha_{1}$ antagonist), ketanserin (5-HT 2 antagonist) and ondansetron (5-HT 3 antagonist). These authors have suggested that antidepressant-induced antinociception existed functional interaction between noradrenergic and serotonergic neurons.

Kesim et al (17) showed that paroxetine, a SSRI drug, produced antinociception in writhing test in mice and paroxetine-induced antinociception is inhibited by ondansetron. Also, the same authors have reported that paroxetine produced antinociception in hot-plate test and this effect is inhibited by ondansetron and naloxone (18).

Schereiber et al (19) demonstrated that reboxetine (selective noradrenalin re-uptake inhibitor) induced dose-dependent antinociceptive effect in hot plate-test in mice. The reboxetine-induced antinociception is inhibited by naloxone. Phentolamine $\left(\alpha_{1}-\alpha_{2}\right.$ adrenergic antagonist) and yohimbine ( $\alpha_{2}$ adrenergic antagonist) did not abolish reboxetine's antinociception. Also, these authors showed that fluoxetine, fluvoxamine and citalopram induced antinoceptive effect but escitalopram did not induce antinociceptive effect and all three drug's effects did not abolish by naloxone (20).

It has been reported in literature that the role of NO is complicated in pain. Kawabata et al (21) reported that peripheral NO has dual effects (nociceptive or antinociceptive) in nociceptive modulation. Moore et al (22) suggested that L-NAME (L-N ${ }^{\mathrm{G}}$-nitro arginine methyl ester) elicited dose-related antinociception in formalin test in mouse. In contrast; L-NAME indicated nociceptive effect in literature (23). The antinociceptive effect of milnacipran and sertraline were reversed by L-NAME in our study.

In our study, milnasipran $(30 \mathrm{mg} / \mathrm{kg})$ and sertraline $(50 \mathrm{mg} /$ $\mathrm{kg}$ ) produced statistically significant analgesic effect compared to their control values after 2 hours in group 2. But these antinociceptive effects were weak compared to group 1 . This result might be related to the tolerance occurred by chronic drug application.

In conclusion, milnacipran and sertraline induced dose-dependent analgesic effects in tail-flick test in mice. All two drug's analgesic effects were reversed by L-NAME, naloxone, ondansetron and prazosin. These results indicated that the analgesic effect of milnacipran and sertraline are related to nitrergic, opioidergic, serotoninrgic and adrenergic system.

\section{References}

1. Cunha TM, Verri WA Jr, Silva JS, Poole S, Cunha FQ, Ferreira SH. A cascade of cytokines mediates mechanical inflammatory hypernociception in mice. Proc Natl Acad Sci USA 2005; 102 (5): 1755-1760.

2. Verri WA Jr, Cunha TM, Parada CA, Poole S, Cunha FQ, Ferreira SH. Hypernociceptive role of cytokines and chemokines: targets for analgesic drug development? Pharmacol Ther 2006; 112 (1): 116-138.

3. Abramson SB, Amin AR, Clancy RM, Attur M. The role of nitric oxide in tissue destruction. Best Pract Res Clin Rheumatol 2001; 15 (5): 831-845.

4. Busch-Dienstfertig M, Stein C. Opioid receptors and opioid peptide-producing leukocytes in inflammatory pain-basic and therapeutic aspects. Brain Behav Immun 2010; 24 (5): 683-694.

5. Joseph EK, Levine JD. Mu and delta opioid receptors on nociceptors attenuate mechanical hyperalgesia in rat. Neuroscience 2010; 171 (1): 344-350.

6. Kivell B, Prisinzano TE. Kappa opioids and the modulation of pain. Psychopharmacology (Berl) 2010; 210 (2): 109-119.

7. Richardson BP. Serotonin and nociception. Ann NYAcad Sci 1990; 600: 511-519. 8. Pertovaara A. Noradrenergic pain modulation. Prog Neurobiol 2006; 80 (2): 53-83. 9. Sawynok J, Esser MJ, Reid AR. Antidepressants as analgesics: an overvriew of central and peripheral mechanisms of action. J Psychiat Neurosci 2001; 26 (2): 1-9.

10. Mico JA, Ardid D, Berrocoso E, Eschalier A. Antidepressants and pain. Trends Pharmacol Sci 2006; 27: 348-354.

11. Jung AC, Staiger T, Sullivan M. The efficacy of selective serotonin reuptake inhibitors for the management of chronic pain. J Gen Intern Med 1997; 12 (6): 384-389.

12. Goodnick PJ. Use of antidepressants in treatment of comorbid diabetes mellitus and depression as well as in diabetic neuropathy. Ann Clin Psychiat 2001; 13 (1):31-41.

13. Verdu B, Decosterd I, Buclin T, Stiefel F, Berney A. Antidepressants for the treatment of chronic pain. Drugs 2008; 68 (18): 2611-2632.

14. Iyengar S, Webster AA, Hemrick-Luecke SK, Xu JY, Simmons RM. Efficacy of duloxetine, a potent and balanced serotonin-norepinephrine reuptake inhibitor in persistent pain models in rats. J Pharmacol Exp Ther 2004; 311 (2): 576-584.

15. Onal A, Parlar A, Ulker S. Milnacipran attenuates hyperalgesia and potentiates antihyperalgesic effect of tramadol in rats with mononeuropathic pain. Pharmacol Biochem Behav 2007; 88 (2): 171-178.

16. Yokogawa F, Kiuchi Y, Ishikawa Y, Otsuka N, Masuda Y, Oguchi K, Hosoyamada A. An investigation of monoamine receptors involved in antinociceptive effects of antidepressants. Anesth Analg 2002; 95 (1): 163-168.

17. Kesim M, Duman EN, Kadioglu M, Yaris E, Kalyoncu NI, Erciyes N. The different roles of 5-HT(2) and 5-HT(3) receptors on antinociceptive effect of paroxetine in chemical stimuli in mice. J Pharmacol Sci 2005; 97 (1): 61-66.

18. Duman EN, Kesim M, Kadioglu M, Yaris E, Kalyoncu NI, Erciyes N. Possible involvement of opioidergic and serotonergic mechanisms in antinociceptive effect of paroxetine in acute pain. J Pharmacol Sci 2004; 94 (2): 161-165.

19. Schreiber S, Frishtick R, Volis I, Rubovitch V, Pick CG, Weizman R. The antinociceptive properties of reboxetine in acute pain. Eur Neuropsychopharmacol 2009; 19 (10): 735-739.

20. Schreiber S, Pick CG. From selective to highly selective SSRIs: a comparison of the antinociceptive properties of fluoxetine, fluvoxamine, citalopram and escitalopram. Eur Neuropsychopharmacol 2006; 16 (6): 464-468.

21. Kawabata A, Manabe S, Manabe Y, Takagi H. Effect of topical administration of L-arginine on formalin-induced nociception in the mouse: a dual role of peripherally formed NO in pain modulation. Br J Pharmacol 1994; 112 (2): 547-550.

22. Moore PK, Oluyomi AO, Babbedge RC, Wallace P, Hart SL. L-NG-nitro arginine methyl ester exhibits antinociceptive activity in the mouse. Br J Pharmacol 1991; 102 (1): 198-202.

23. Hashemi M, Karami M, Zarrindast MR, Sahebgharani M. Role of nitric oxide in the rat hippocampal CA1 in morphine antinociception. Brain Res 2010; 131 (3): 79-88. 